\title{
(c) $(1)(9)$ \\ Decolonising legal education in South Africa: Is it time to press the reset button?
}

\section{Michele van Eck}

University of Johannesburg
Journal of Decolonising Disciplines

Volume 2, Issue 1 (2020)

eISSN: 2664-3405

DOI: https://doi.org/10.35293/jdd.v2i1.45

\section{Abstract}

South Africa has, like many other African countries, inherited a foreign legal system. The democratic Constitution of 1996 altered the country's legal framework such that it became reflective of societal change, while recognising plurality in South African legal culture(s). Owing to the 2015-2016 \#FeesMustFall student protests, another ideological shift in legal education is being precipitated by the changing socio-political landscape of the country. This shift is framed as decolonisation, which entails shedding the colonial yoke of exclusive western ideologies and thinking, thereby requiring an inclusive educational approach. Such a transformed education would incorporate local African traditions, customs and ideologies that existed prior to colonial imposition. Legal thinking and culture is dependent on legal education, and legal education is consequently reliant on the legal framework. Considering this chain of influences, I argue that decolonisation cannot be achieved merely as a change in legal education alone: it requires an ideological shift in the country's legal framework.

Keywords: legal education, decolonisation, legal history, indigenous law, customary law. 


\section{Introduction}

Until recently, many thought that South Africa's societal and economic change pivoted around the final Constitution of the Republic of South Africa of 1996. The Constitution was indeed a necessary step in the political decolonisation of South Africa (Molope \& Mekoa 2018). It has, however, become apparent that the influence of colonialism was more than political - suggesting the need for further efforts in decolonising contemporary society, which is still captured by its past (Mamdani 2001). The claim for contemporary decolonisation was substantiated by the 2015-2016 \#FeesMustFall student protests, in which South African students demanded not only affordable (and in some cases free) education, but also an ideological shift in higher education (Chaka, Lephalala \& Ngesi 2017). The call for decolonisation, in this context, signified a symbolic and performative act of shedding the colonial yoke epitomised by western ideologies and thinking in education. Decolonisation demands a move towards an inclusive educational approach that incorporates local African customs, ideologies and traditions that existed prior to colonial imposition in the country.

Change in education is not new in our South African context and its origins can be traced to a historical system that provided unequal education based on race classification (Chaka et al. 2017; Kader \& Wilmot 2001). To demonstrate, the reader ought to consider the Bantu Education Act (1953) and the Extension of University Education Act (1959), which incorporated policies that separated education on the basis of race, and ultimately resulted in the separate development of universities in the homelands (Iya 2001). It is not surprising, therefore, that early on in South African democratic society, legal education became one of the principal focus areas in attempts at transforming institutions of justice (Iya 2001). Notwithstanding the new wave of reforms in education post-1996, legal education has remained largely 
influenced by established western traditions (Kader \& Wilmot 2001). ${ }^{1}$ Nevertheless, inroads were made, with the Qualification of Legal Practitioners Amendment Act (1997) being one of the pivotal pieces of legislation that sought to change legal education in the country (Iya 2001). ${ }^{2}$ Contentious as it may sound, educational reform is presently incomplete. The present challenge that higher education, and more specifically, legal education faces can be framed as the need to shift away from a purely Eurocentric focus. This can be achieved only by successfully decolonising curricula and changing the general manner in which the law is taught (Iya 2001). In my argument, I frame the process of decolonisation as rooted in the mind (following in the tradition of Ngũgĩ wa Thiong'o 1986) and which I believe is foundational to the success of institutional education reform in South Africa. This argument is made with the aim of addressing the challenges witnessed in higher education, which (the 2015-2016 \#FeesMustFall student protests have highlighted) may still be largely modelled after western thought and tradition and have not adequately taken into account African culture, thought and tradition.

Legal education differs from other disciplines. This is due to the content of the discipline, which is based on the established legal framework in the country at a given time. In this schema, the country's legal framework dictates the content and form of legal education. This constraint provides a unique challenge in a country where the legal system is entrenched in and embraces western tradition, precedence and legal heritage. The challenge in this respect is that the law may only be partially inclusive, or in some instances, exclusive to that of African customs, cultures and approaches. Simultaneously, the legal system provides a different dimension and new possibilities to the process of the decolonisation of legal education. This paper proposes that educational legal reform cannot be fully realised in only changing the legal curriculum but should also include a change in the country's legal framework.

It is useful for the reader to bear in mind that South Africa's legal framework is

1 The origins of western legal tradition comprises of three major elements, being: (i) the rediscovery of the Roman law as recorded by Emperor Justinian; (ii) the method in which legal texts were analysed in the 'the method of analysis and synthesis', or referred to as 'scholasticism'; and (iii) being the teaching of law in a university context (Berman 1977:900). These law schools were also, to some extent, influenced by religious structures within Europe at the time, however, they had (for the first time) started to develop legal principles in 'autonomous, integrated, developing body of legal principles and procedures' (Berman 1977: 896). The legal curriculum at this time was to study these documents (Berman 1977). Roman-Dutch law developed from this background and ultimately (albeit indirectly) informed the South African legal landscape.

2 Another change in the legal landscape was introduced in the Legal Practice Act (2014). 
not stagnant and can be changed by legislative intervention (albeit always subject to the values enshrined in the Constitution). Any changes to the legal framework will naturally influence the content of legal education. While there certainly is a need to change the discipline, teaching approaches, and the curriculum to meet contemporary challenges, such changes cannot be achieved through legal education alone. I maintain that change is augmented by ideological shifts in the legal framework itself (Kader \& Wilmot 2001), and different approaches could either assist or delay decolonisation. Three approaches that would provide positive change to the law have been identified and are discussed in this paper: (i) the natural progression and development of the legal framework in South Africa; (ii) a piecemeal approach wherein legislative interventions are introduced in order to incorporate local customs and traditions into pre-existing legal frameworks; and (iii) a more radical approach in which not only customary law, but the entire legal framework can be either restated or codified for the unification of the western approach and local African customary principles that are imbedded within local understandings. These approaches will be considered so as to determine the one best suited to drive decolonisation, not only with respect to legal education as a discipline, but also the decolonisation of the legal framework in the country.

\section{Transplanted Legal Systems}

The characteristic feature of almost every country on the African continent is that they have (in some way, shape or form) a colonial legal heritage (Allott 1984). Inherited legal systems in Africa are rooted in colonial influences of the British, French, Dutch, Italian, German and Portuguese (Cotran 1983). This consequently led to the development of legal pluralism wherein both the imposed foreign legal system and local customary laws operated, in some African countries, more cohesively than in others (Allott 1984).

Similarly, South Africa possesses an inherited legal system. The story of western legal tradition in South Africa starts in 1652 when the Dutch East India Company established the Cape of Good Hope as a refreshment station for traders who brought along with them Roman-Dutch law (which is a combination of Roman law, German law, the law of Merchant and Canon law) (Lokin 2008; Sanders 1981). These traders, who found themselves on the southernmost tip of the African continent, established a legal tradition in the Cape colony that incorporated the framework of 
rules and principles of the Roman-Dutch law, which was used practically and within established institutions (Thomas 2008). The Roman-Dutch law applied exclusively until 1795 when the British Empire took control of the Cape colony (Sanders 1981). In 1803, the Dutch retook control of the Cape for a short period of time and in 1806 the British Empire again established its control of the Cape colony (Sanders 1981). Although Roman-Dutch law remained the basis of the law in the Cape colony, various legislative interventions that were brought about during English rule infused English legal principles into the legal system (Sanders 1981). For example, when RomanDutch law was silent on a matter, then the courts would look to the English authorities in order to find answers to legal queries (Thomas 2008). Furthermore, English influences were prevalent in areas such as administrative law, law of procedure, law of evidence, company law, as well as various other areas of the law (Sanders 1981). This combined legal system, as developed in the Cape colony, was instituted throughout South Africa in various ways, and took hold in the other colonies of Natal, the Boer republics of the Orange Free State and the Zuid-Afrikaansche Republiek that were established as a result of the Great Trek (Thomas 2008).

Due to the English rule of the Cape colony, changes were brought about not only to language, culture, economy, trade, political and religious ideologies, but also to legal traditions (Hahlo \& Kahn 1968; Thomas 2008). It can be said that two streams of legal principles (i.e. Roman-Dutch and English law) developed in South Africa both substantively and procedurally (Lokin 2008). It is as a result of both the influence of the Roman-Dutch and English law that the South African system is often referred to as a mixed legal system with pluralistic characteristics in which various legal systems and cultures operate (Iya 2001). The four colonies shared the common law which comprised predominantly of these two legal streams but were influenced by the different legislatures and judicial interpretations of each of the colonies (Thomas 2008).

In addition to the Roman-Dutch and English legal streams (what is referred to as South African common law), a third legal stream existed prior to the colonisation of South Africa, this being African customary law (or often referred to as indigenous law), which - after the colonisation of South Africa - was always subordinated to, and judged against its western counterparts. Examples of the first recognition of customary law can be found in the Natal Ordinances in which chiefs would determine disputes within their tribes based on customary law, and later the Natal Codes that were promulgated, which regulated all disputes of the indigenous population (Thomas 
2008). Indigenous law was also recognised in the Black Administration Act (1927), a legislative mechanism that gave recognition to customary law, provided that it did not conflict with public policy. In essence the western legal tradition distinguished between those persons who were considered to be indigenous and those persons who were not, thereby establishing different rules and laws that applied to different inhabitants of the country (Mamdani 2001). Through this framework the pluralistic nature of the legal systems in South Africa was both established and reinforced.

\section{Survival of African Customary Law}

Prior to the colonisation of South Africa, the inhabitants of the country functioned and operated under the auspices of customary law. The distinction between different customary laws within the country was not necessarily based on race but rather on ethnicity, and thereby one could state that each ethnic group had its own governing set of customary legal rules (Mamdani 2001). These groups were historically identified through language, culture, law and custom, and South Africa mainly distinguished between the Nguni, Sotho-Tswana, Tsonga and Vhavanda as indigenous groups of people of South Africa (Bekker 1989).

One of the unique characteristics of customary law is its ability to adapt to circumstances and thereby function with some flexibility. It was probably due to this very characteristic that customary law was not originally recorded in writing (Ndima 2003; van Niekerk 2011), and thereby created a challenge for western legal thought to establish the exact rules of the various branches, and the operation of customary law.

Customary law can be grouped into three broad categories (being autonomous, official and academic customary law). The first category that is called autonomous customary law (or often referred to as living customary law), describes the functioning of customary law prior to western influence (Sanders 1987). As customary law is considered to be flexible, self-regulatory and is not fixed to specific written forms, it would naturally and organically adapt to the needs of the community (Sanders 1987). In doing so, customary law would always be reflective of the community's societal structures and requirements. The principles of customary law would be taught by word-of-mouth from one generation to another (Bennett \& Vermeulen 1980). The nature of customary law (in the past and the present) was summarised in the Constitutional Court case of Alexkor v Richersveldd Community (par. 53): 
In applying indigenous law, it is important to bear in mind that, unlike common law, indigenous law is not written. It is a system of law that was known to the community, practiced and passed on from generation to generation. It is a system of law that has its own values and norms. Throughout its history it has evolved and developed to meet the changing needs of the community. And it will continue to evolve within the context of its values and norms consistently with the Constitution.

To the western-trained legal mind, this naturally brings about questions of consistency of legal application and the fallibility of an individual's memory over extended periods of time (Bennett \& Vermeulen 1980). Such a concern stems from a legal positivist approach in which one expects the law to be found in tangible sources that are academically accessible (Himonga $\&$ Nhlapo 2014). ${ }^{3}$ It is likely that this was the causal reason for customary law branching into two further artificial categories, being official customary law and academic customary law (Sanders 1987). Official customary law is a prime example of how western society's need for predictability and certainty, forced written accounts of customary law (Sanders 1987). The very process of codifying customary law is aligned with legal positivism and seemed to strip autonomous customary legal system from its basic functional characteristics of flexibility. Although customary law is recognised in the Constitutional democracy of South Africa, this occurred in a context of weak-pluralism in which the State has the authority to override customary legal principles through legislation (Rautenbach \& Bekker 2014). In occupying this subservient legal position to State law, official customary law went further by eliminating those elements of autonomous customary law that were found to be undesirable and did not conform to the western worldview at the time (Sanders 1987). This process included the selection and codification of some aspects of customary law while disregarding other aspects altogether (the authority for this was often found in the repugnancy proviso that existed in many customary law codifications). An example of such a codification can be found in the Natal Codes. (Dlamini 1992).

This process of establishing an official customary law resulted in transposing, at least to some level, western thinking and approaches into the codified customary system, and thereby irreparably distorting the original features of customary law

3 This likely stems from the origin of western legal tradition that is referenced in footnote 1 (above). 
altogether (Ndima 2003; Sanders 1987). Another general feature of customary law is that individuals did not necessarily have a central authority to appeal to (a reality that came into being owing to western traditions) but were accountable rather to a number of authorities within their community, such as certain age groups, woman groups, chiefs and so on (Mamdani 2001). These structures were less formal than their western counterparts, and the chiefs required the cooperation of their private council for certain actions, such as making laws and calling assemblies (Myburgh 1985). Their private council, which consisted of certain family members and close confidantes, was not formally composed, whereas community councils included the head of every ward (Bekker, Rautenbach \& Goolman 2006). An example of such a structure can be found in the system of the Nguni Chief, who could not make a decision alone or go against the general wishes of his tribe (Hammond-Tooke 1964). The authority of the chief and his function in tribal communities was unfortunately misconstrued and misinterpreted by western tradition, and this misunderstanding was ultimately reinforced in the process of indirect rule and the codification of customary law (Hammond-Tooke 1964). Special courts (such as the Native High Court and the Native Appeal Court in Natal) were also established to adjudicate indigenous legal matters, and thereby severed another essential feature of flexibility in the original functioning of customary law (Dlamini 1992; Mamdani 2001). The introduction of the Black Administration Act (1927) reinforced the concept of special courts, wherein the chief or headsman would have jurisdiction over certain criminal matters and could adjudicate civil matters of a customary law nature (Olivier, Bekker \& Olivier 1995). Another example of such reinforcing legislative framework can be found in the Traditional Leadership and Governance Framework Act (2003) (Bekker et al. 2006).

The final category of customary law can be described as academic customary law, which is an academic study of customary law and practice (Sanders 1987). This process considers the orthodox or ideal manner of acting and is often theoretical at its core. The academic and theoretical process of studying customary law may be considered artificial and not reflective of the actual customary practices (Sanders 1987). If one argues that the educational process is infused with western thinking, then the process of analysing customary law in such an academic and theoretical exercise could also result in the undesired effect of transplanting western legal and academic approaches, thereby creating an unauthentic reflection of autonomous customary law. As a result, it is necessary to change the traditional academic approach 
to studying customary law. Rather than relying on academic sources, an empirical and practical approach is necessary to study customary law and its traditions and practices at a particular time and for a particular matter. As Alexkor $v$ Richterveld Community (par. 54) puts it, 'caution must be exercised when dealing with textbooks and old authorities because of the tendency to view indigenous law through the prism of legal conceptions that are foreign to it'.

These three categories of customary law (i.e. autonomous, official and academic customary law) currently exist in South African society to a greater or lesser extent; however, all three are considered to be different (see par. 150 of the dissenting judgment of Bhe and Others $v$ Magistrate, Khayelitsha). It is clear that customary law is part of the fabric of South African society; however, the legal mind must be cautioned against looking at the customary legal system through a western lens. This was perhaps most aptly summarised in the dissenting judgment of Bhe and Others $v$ Magistrate, Khayelitsha (par. 154):

The evolving nature of indigenous law and the fact that it is unwritten have resulted in the difficulty of ascertaining the true indigenous law as practiced in the community. This law is sometimes referred to as living indigenous law. Statutes, textbooks and case law, as a result, may no longer reflect the living law. What is more, abuses of indigenous law are at times construed as a true reflection of indigenous law, and these abuses tend to distort the law and undermine its value. The difficulty is one of identifying the living indigenous law and separating it from its distorted version.

It then seems clear that living customary law must be a recognised version of customary law in South Africa (as it is in the Constitution). As living customary law is not recorded in writing, such customs of the cultural group would have to be established to determine the particular set of legal rules that are applicable in any specific circumstance. These legal rules are established by meeting four requirements, which are set out by Rautenbach \& Bekker (2014) as follows: (i) the custom must have been in existence for a long time; (ii) the community must generally observe the custom; (iii) the custom must be reasonable; and (iv) the custom must be consistent with the Constitution and other legislation. A form of weak legal pluralism is established by comparing customary law to these four requirements (Himonga \& Nhlapo 2014). In addition, these requirements are qualifications to the recognition 
and enforcement of customary law in modern South African legal processes that seem to have undertones of the repugnancy clauses that had been introduced in South Africa and into a number of African legal systems. Take for instance, Ghana (which had such a repugnancy clause until 1960) and Nigeria, in which customary law would not be applied if it was found to be contrary to 'natural justice, equity and good conscience' (Danner \& Bernal 1994: 174-175). Such repugnancy clauses also historically existed in South African legislation, such as section 1(1) of the Law of Evidence Amendment Act (1988) and section 11(1) of the Black Administration Act (1927) (Olivier et al. 1995). The logic behind such repugnancy clauses was to moderate customary law against western legal principles and values (Danner \& Bernal 1994). The contemporary South African process of moderating customary law and comparing such traditions and customs against the Constitutional framework could have a similar effect as that of a repugnancy clause and may continue to infuse western-based legal thinking in the recognition and application of customary law. This is particularly the case if the Constitution itself is viewed as a product of western thought and tradition. On the other hand, even though the concept of a constitution is western in origin, our courts have recognised that the Constitution reflects the cultural heritage of the principle of Ubuntu that defined 'the whole constitutional order' (Port Elizabeth Municipality v Various Occupiers 2004: 1288), and links to the 'spirit, purport and objects of the Constitution' (Everfresh Market Virginia (Pty) Ltd v Shoprite Checkers (Pty) Ltd 2012: 227).

Notwithstanding this, the Constitution recognises customary law as a separate legal and cultural system that can be used by persons that desire to do so, but such recognition is based on the proviso that customary legal principles would be recognised and applied only if they are consistent with the Constitution (Rautenbach \& Bekker 2014). Therefore, South Africa houses two distinctly different legal systems, the first premised on western principles (being the common law that reconciles two of the legal streams of Roman-Dutch and English law) and the other based on indigenous identity, ontology and customs (African customary law) (Rautenbach \& Bekker 2014). ${ }^{4}$ Therefore, in light of the call for educational reform, it is clear that, although there are two distinct legal systems at play in South Africa (which are already taught at higher education institutions), the investigation of the

4 The South African legal framework similarly accommodates other customs and religions that are be practiced in South Africa. 
decolonisation of legal education must then turn to other possible considerations of the legal framework, such as partial or complete unification of either the common or customary law (or both), and even perhaps reconsidering the common law itself.

\section{Unification of Legal Framework, Thought and Education}

It can then be said that the legacy of colonisation has left its mark on Africa, seen in the Anglo-American traditions found in countries like Ghana, Nigeria, Sierra Leona, Kenya and Uganda (Gower 1967). Broadly speaking, these traditions have incorporated the British-styled education system and educational approach (Gower 1967). The steps to decolonising inherited legal educational structures requires that: (i) the requisite knowledge (that is to undergo decolonisation) should be identified; (ii) the curriculum be defined; (iii) change be brought to what is taught and how it is taught; and (iv) the process should be undertaken as a holistic approach (Chaka et al. 2017). Legal thought and culture cannot be changed solely by means of legal education alone, and legal education does not, in itself, function in a vacuum. Rather, there exists a complex set of interrelated factors that must wax and wane in order to bring about change to legal thought, culture and ultimately legal education within a country. Therefore, changing the curriculum and the manner of teaching to achieve decolonised legal education, is but one element in a long chain of influences. At the epicentre of legal thought, culture and education is the country's legal framework that consists of legal norms (Hahlo \& Kahn 1968). It can be argued that we derive many influences from the legal framework and that changes to the legal framework could result in changes within a country's legal thought, culture and even legal education.

The legal framework of a country should be reflective of social needs and values, and consequently legal education would naturally adapt and develop to provide the necessary educational needs within the legal framework of the country. A failure to reflect and meet the requirements of society would effectively render the educational system useless. This process of change was initiated in 1996 with the advent of the final Constitution that ultimately reflects societal values in the country. Since then, the legal curriculum adapted to the country's constitutional dispensation, and many laws (including legislation and customs) have been discarded, changed or adapted to align with the societal values reflected in the Constitution. The questions that the 2015-2016 \#FeesMustFall student protests raised, considered the effectiveness of changes in the South African constitutional dispensation and whether these changes 
were enough truly to decolonise higher education. These sentiments echo the view that the current South African legal theoretical framework predominantly prepares students for a western-based legal system (Himonga \& Diallo 2017), and thereby hampers 'new perspectives, alternative views and different arguments or ways of thinking' (Van der Walt 2006: 18). It is possible, due to the societal shift in South Africa since 1996 and the aspirations that came with the transition, that the higher education system has not adequately addressed the need for societal and economic changes that have fully championed the principles of 'redress, social justice and democratisation' (Koma 2018: 100).

In order to achieve such an ideological shift within the sector of higher education, the appropriateness of the pluralistic legal framework (upon which legal education rests) must be considered. There are generally three approaches suggested that would propel the decolonisation of the legal framework: (i) a natural progression and development of the legal framework in South Africa; (ii) a piecemeal approach wherein legislative interventions reconfigure local customs and traditions such that they fit into the existing legal structures; and (iii) a more radical approach whereby it is not only customary law but the country's entire legal framework that are restated or codified for the unification or consolidation of the western approach and local African customary principles, ideologies and traditions. ${ }^{5}$

\section{Natural Progressive Approach}

At the rise of the new democracy, there was a need to sever discriminatory laws of the apartheid era and rid the South African legal system of its historical legal baggage. In doing so, it was believed that the South African legal system could recover and organically adapt to the requirements and values of a new Constitutional dispensation (Van der Walt 2006). The view, until recently, has been that the Constitution had redefined and consolidated African and western values in the South African context (Lemmer \& Olivier 2000). This view was supported by the contention that the Constitution is, at its core, a political document with a transitional purpose that is reflective of the whole society and intended to revive African values that had in

5 Unification in this context is not intended to mean that African customary law and the common law should be integrated. Rather, it is meant to address unified or consolidated legal principles that is coherent, relevant and applicable to all members of South African society. 
the past been suppressed by western tradition (Lemmer \& Olivier 2000). There has, however, been a recent intellectual shift in this view and criticism has been raised against the appropriateness of constitutionalism in South Africa. There have even been suggestions that such a continued approach would be unsustainable in the long term, and this viewpoint can be summarised as follows:

[B]y failing to address the problem of historical and corrective justice, the new legal and political order would ultimately reveal irresolvable cracks and tensions that would overwhelm the coherence of the very idea of 'postapartheid South Africa'. (Modiri 2019:29)

There may be some merit to such arguments as the concept of a constitution is, at its core, a product of western legal thought, and the notion of liberal and democratic constitutionalism is rooted - according to popular discourse - in the concept of a social contract that was historically used to illustrate the origin of state power in relation to a country's citizens (Rosenfeld \& Sajó 2013). On the African continent, inherited 'post-colonial' constitutional models are prevalent, and the fallout of such constitutional models can be characterised as a continued struggle of accepting and using western thoughts, systems and ideologies (Rosenfeld \& Sajó 2013). ${ }^{6}$

The South African Constitution contains legal norms that emanate from political decisions (Rosenfeld \& Sajó 2013). The source of such political decisions can be traced back to the abolishment of apartheid in 1994 and the introduction of transitional measures in the interim Constitution of 1993, and, later, to the final Constitution of 1996. The South African Constitution contains key characteristics, such as establishing public power to govern the country and is viewed as a higher form of law than other laws in the country (Rosenfeld \& Sajó 2013). Furthermore, African customs and values, such as the principle of Ubuntu, had been taken into account when the Constitution was initially drafted (Lemmer \& Olivier 2000). The value of Ubuntu, as highlighted by Justice Mokgoro, is a principle that has been accepted as part of the South African legal structure, and was loosely translated by the court to mean 'humaneness, personhood and morality' ( $S$ v Makwanyane and Another 1995:

6 The term 'post-colonial' in this context refers to the political freedom afforded after the official end of colonialism and is not intended to suggest that other western or colonial influences have not been embedded within the social-economic fabric of the African continent. 
672). This principle reflects 'the key values of group solidarity, compassion, respect, human dignity and collective unity', and also encompasses the concept of 'respect and value for life in the concept of humanity', while giving 'meaning and texture to the principles of a society based on freedom and equality' ( $S v$ Makwanyane and Another 1995: 672).

Constitutional democracy has traditionally been seen as a 'pattern of legitimation and organization of public power' (Rosenfeld \& Sajó 2013:107); however constitutional democracy in many countries seems to be declining, and several constitutional democracies have been described as being in crises, with the South African constitutional dispensation being one of them (Graber, Levinson \& Tushnet 2018).

Notwithstanding the perceived conceptual flaws of the continued use of the constitutional legal structure in South Africa, our courts have noted that 'constitutionalism has become central to the new emerging South African jurisprudence, [and] legislative interpretation will be radically different from what it used to be in the past legal order' (S v Makwanyane and Another 1995:768). As a result, there is still strong support for the appropriateness of the Constitution and arguments have been made that the perceived failings of the Constitution are not necessarily a legal failure but rather a political failure (Le Roux \& Davis 2019). Although the debate on the appropriateness of South Africa's constitutional dispensation falls outside the ambit of this paper, it is useful to note that there are indeed different views as to the appropriateness of the current constitutional dispensation of South Africa.

For the purposes of this paper it is worth noting that the Constitution of 1996 marked a major ideological shift within the South African context. The four corners of the Constitution house the basic values on which the entire societal and legal structure rests, and also defines South Africa as a pluralistic legal system (Hutchison \& Sibanda 2017). The South African legal system therefore recognises both common and customary law, and confirms that the courts must apply customary law insofar as it is relevant in a particular set of circumstances (see section 211(3) of the Constitution). The Constitution also recognises traditional leadership (section 211) and highlights that the courts must apply customary law when the law is applicable (which remains subject to the Constitution) (section 211(3)). ${ }^{7}$ The South African

7 This paradigm may create a conflict within the recognised legal systems within South Africa, however, it is not the intent of this article to explore these aspects. 
courts have been given the legislative power to interpret living customary law, whereby the courts are not bound to the western influences of interpreting codified and academic customary law in adjudicating a dispute (Ndima 2003).

Customary law is therefore recognised in South Africa as a distinct and separate legal system and is taught within legal education as such. The Constitution should theoretically reset the laws of South Africa and align them to the values reflected by the Constitution. It is for this reason that the approach of South Africa's constitutional dispensation can be described as a natural progressive approach that, over time, corrects historical and legal discrepancies and prejudices. Although the concept of a constitution itself stems from western tradition, the content of the South African Constitution can be described as transitional and reflective of African values.

Unfortunately, there are major shortcomings with the natural progressive approach. The first is the reality that notwithstanding the recognition of customary law in the Constitutional framework, customary law remains subject to the provisions and values of the Constitution. This could be problematic if one argues that the Constitution itself, in structure and substance, is a product of western legal thought and tradition. If this is the case, then customary law would continue to be infused with western legal thinking and tradition. This shortcoming becomes conceptually less problematic if, rather than considering that the constitutional framework has a western heritage, one considers the substantive values of the Constitution which have taken into account African values, customs and thought at its inception and are reflective of societal views. This notwithstanding, the natural progressive approach may not be a completely satisfactory approach for the majority of South Africans that may not have practically experienced the values enshrined in the Constitution (largely due to the long timeframes for the approach to yield substantive changes in the country). The second apparent shortcoming is the timeframe for such corrective mechanisms to bear fruit. In simple terms, due to this process being organic in nature, it is inherently slow. These long periods of time and the typically reactive (rather than proactive) nature of the legal system could result in a nation having to wait for many decades to pass before the remainder of the legal framework has sufficiently been updated to be reflective of change. This has been the unfortunate reality for many South Africans, who had not necessarily seen a reflection of the Constitution in their cultural framework. One ought also to consider that due to such a slow and reactive process legal education remains only partially decolonised. The result of this reality is the dwindling opportunity for change in the country. 


\section{Piecemeal Approach}

The piecemeal approach is, in the first sense, premised on the Constitutional dispensation in that it is constitutive of a process of introducing specific sets of legislation, with the intent to amend certain areas of law so as to change the common law, fill in the gaps that the common law does not address or be more inclusive of customary, ethnic and cultural identities of the country. The piecemeal approach is not necessarily limited to customary law and can legislatively intervene in other areas of the law (as it has in common law) to bring about change. Such changes to the law must, however, develop in line with Constitutional values. It is useful to note that such an approach must be undertaken on the basis that the Constitution is reflective of the beliefs and values of society, and that such values are central to modern South African jurisprudence ( $S$ v Makwanyane and Another 1995)

Typical examples of such legislative interventions in customary law can be found in the Recognition of Customary Marriages Act (1998) as well as Reform of the Customary Law of Succession and Regulation of Related Matters Act (2009). These are legislative mechanisms that not only recognised customary marriages and succession rules, but have codified and adapted these customary rules such that they are consistent with the current Constitutional values (Himonga \& Diallo 2017). Other examples exist that apply in an indirect manner and mark changes to the law in general. It has been recognised that protection must be afforded to the vulnerable in society and this includes protection from the exploitation of individuals in consumer environments. The Consumer Protection Act (2008) and the National Credit Act (2005) provides legal protection for consumers in consumer, lending and borrowing environments (see further examples: Restitution of Land Rights Act (1994) and the Land Reform (Labour Tenants) Act (1996)). ${ }^{8}$ These are but a few examples that demonstrate how legislative intervention has brought about a shift in

\footnotetext{
8 For example, the preamble to the Consumer Protection Act (2008) recognises that ' $t$ ] hat apartheid and discriminatory laws of the past have burdened the nation with unacceptably high levels of poverty, illiteracy and other forms of social and economic inequality', and that there is a need to employ innovative means to give effect to the rights of 'historically disadvantaged persons and to promote their full participation as consumers. The National Credit Act (2005) also envisages the non-discriminatory credit marked, by stating in its preamble that one of the intentions to the Act is ' $[\mathrm{t}$ ] o promote a fair and non-discriminatory marketplace for access to consumer credit and for that purpose to provide for the general regulation of consumer credit and improved standards of consumer information'.
} 
the legal framework, thereby highlighting the changes that have been necessitated, indirectly, in curricula of legal education.

Unfortunately, the piecemeal approach relies on sporadic legislative intervention to steer the rudder of change within the South African legal framework. This approach is, at its core, a drive for legal positivism that is rooted in western legal traditions. Therefore, although the legal framework may be updated, there is a need to make changes in order to impact the legal framework to such an extent that it reflects changes in the legal culture of the country. A risk of introducing too many changes too often through the piecemeal approach is that legal principles may remain in flux with continuous changes stymieing the opportunity for legal mechanisms to settle and mature, thus infusing the culture of the country. Put differently, with this mechanism used indiscriminately, a flurry of legal interventions may introduce a level of uncertainty.

\section{Radical Approach}

A combination of the natural progressive and the piecemeal approaches have been prevalent in the South African legal framework since 1994. It has undoubtedly brought change to the legal framework and, consequently, to legal education. It is questionable whether these approaches have provided the necessary change in the short term to effect the deep-rooted change that is necessary for the decolonisation of legal education. Therefore, the current legal system could be described as an uneasy co-existence of the new constitutional dispensation with that of the past (Dlamini 1992). The present legal framework that exist in the country could, however, also be indicative of the belief that natural progressive and piecemeal approaches will eventually bring about the desired changes, but this would occur over a long period of time. It is, however, clear from the 2015-2016 \#FeesMustFall student protests that society requires more immediate change. After all, although common law (in particular Roman-Dutch law) has inherent equitable attributes, 'apartheid legislation effectively undercut the equitable principles of Roman-Dutch law' and thereby created a perception that the common law works against specific demographics, people and cultures within the country (Dlamini 1992:137).

If change is to be achieved in a shorter timeframe and if the negative perceptions of the law are to be addressed proactively, it is perhaps then worth considering a more radical approach in changing the South African legal framework as a whole. 
This could be achieved by restating the law, which would be 'a written expression of the rule of law' including both customary law and common law, thereby reconfiguring the legal framework such that it is not only seen to be, but substantively engages with the reality of the majority for the purposes of bringing about substantive change (Levasseur 1976: 402). The restatement of a legal system would typically only be undertaken in instances where there is uncertainty regarding legal principles and where there is a need for consolidation of various legal rules. The alternative is to consider the codification of the legal system into either comprehensive legislation dealing with a particular legal discipline (such as a criminal code) or incorporating the entire law into a civil code. Such radical approaches would constitute legal reform and would result in an immediate change to the legal framework and subsequently what is taught in institutional legal education.

Restatement of the law will not necessarily bring about change to the existing legal framework, but is rather a confirmation of the existing law. Therefore, my focus is on codification, which is a process of resetting the legal framework and can be described as the consolidation of legal rules into concise principles (Gahan 1922). Codification has been used in western and African countries alike. Western countries finds two extremes in codification, the first being either a system of abstract principles (seen in the French Civil Code of 1804), or the second being a concrete approach in which the rules are set out more rigidly (seen in the German Bürgerliches Gesetzbuch of 1900). Codification in European countries was an attempt to consolidate various laws and also update the law to the social and economic needs of the time (Gahan 1922). The advantages of codification were for the law to be brought up-to-date and allowed the law to address modern challenges faced in Europe at the time (Gahan 1922). ${ }^{9}$ Although similar strides could be argued to have been made in South Africa, at the dawn of democracy, another advantage of codification would be an updating of the legal framework so as to consolidate and (where appropriate) unify, along with changing the legal approach in South Africa altogether and address any identified deficiencies within the current legal structure.

Codification is not limited to Europe and has been used in the African context, predominantly in the past, to consolidate customary laws with State law, such as the Zulu and Natal codes, as well as the Black Administration Act (1927) (Himonga

9 A more contemporary example can be found when the French undertook a similar approach in updating the law of obligations in their Civil Code in 2016. 
\& Diallo 2017). Other African countries have also embarked on the process of codification. The Republic of Senegal makes for a good case-in-point having inherited the French Civil Code as part of its legal system and subsequently having experienced challenges in adapting such a European legal system to its developing society (Farnsworth 1964). Some had suggested that the incompatibility was as a result of the effluxion of time since the inception of the French Civil Code, however, many believed that the French Civil Code had simply become inappropriate for the country (Farnsworth 1964). Another point was that the French Civil Code was specifically designed for European social and economic conditions, which made it inappropriate for use in the Republic of Senegal (Farnsworth 1964). Against this backdrop, Senegal embarked on a process of reforming its private law (Farnsworth 1964). Further examples of codification can be found in Ethiopia (Krzeczunowicz 1963), Madagascar (Bennett \& Vermeulen 1980), Ghana (Archer 1987), as well as the Republic of the Ivory Coast (Levasseur 1976), countries that have also aimed to incorporate an civil code in their legal systems. These models of codification could suggest 'an evolution from the original customary to a new system [that], while founded in tradition, is adapted [to] the needs of a modern state' (Bennett \& Vermeulen 1980: 209).

There is, however, no clear-cut example of successes or failures in the process of codification on the African continent, but there are certainly some benefits. The codification of Ivory Coast's law was inspired by a political decision for legal reform and was reflective of social revolution as opposed to a social evolution (Levasseur 1976). It was constitutive of a codification rather than restatement of the law, and also was initially viewed with controversy and criticism (Levasseur 1976). It was perhaps due to its extensive approach (including the codification of certain customary legal aspects of the country) that it was critiqued (Levasseur 1976). Yet, it appears to have been a viable route for legal reform in the country (Levasseur 1976).

Likewise, Ghana has embraced codification, including, for example Criminal Code (1960) and the Criminal Procedure Code (1960) (Archer 1987). One benefit of such codes has been the accessibility of the law to the general population (Archer 1987). Codification, in this context, points towards a greater acceptance and harmonisation of the laws, thereby moving away from the hereditary legal principles that may not be appropriate or useful in a particular country (as was the case in the Republic of Senegal) (Essien 1994).

Codification could be a serious consideration in developing countries where the 
common law principles are out of date, but perhaps codification could also be seen as a legal (and possible political) break-away from a legal framework that embodies almost exclusively western traditions (Archer 1987).

Codification could be used to create a consolidated and unified legislative framework of both common and customary law, thereby resulting in a radical shift in the country's legal framework, which would have a natural impact on legal thought, approach and even legal education. The challenge found in South Africa (and many other African countries) is that both the common law and the customary law would have to be codified for such a radical approach to be successful, which would result in little difference to the current position of academic customary law. South African customary law is largely based on a worldview that is inclusive of cultures, traditions and religion. This interrelatedness of the law and societal conduct would create difficulties in compartmentalising a different State law that is divergent from locally accepted customs. Consequently, codification would seem unlikely to succeed (Berat 1991). Even with such challenges, it would still be possible to codify the common law.

Codification of the common law was previously suggested by some academics in South Africa, but the debate with respect to this approach seems to have dissipated, and dare one say almost forgotten (Cloete 1991). It is perhaps worth considering resurrecting this debate in light of the unique position in which South Africa finds itself and of the call for decolonised legal education that is ultimately premised on the legal framework of the country. The process of codification may, under these circumstances, function as a restorative tool of African values, traditions and customs in the South African legal framework.

\section{Conclusion}

Decolonisation takes many forms and has been traditionally thought of as merely the unshackling of the political constraints of western colonised systems. Western influence is much wider and permeates the very core of individual minds and our institutional frameworks that have effectively left a western structural and legal legacy in South Africa (Gower 1967). The kernel of the issue can perhaps best be summarised by stating that, "[d]espite the fact that African countries were at some point in their histories declared politically free, their health, economic, political, legal and educational systems remain trapped within their ex-colonisers' frameworks and practices' (Molope \& Mekoa 2018: 140). 
In light of decolonisation, legal education should provide an inclusive educational experience of all traditions, thoughts and developments such that it equips graduates with skills that are required for the distinctly unique challenges that are presented by the South African socio-political milieu, as well as those of an integrated and globalised world. This process includes a decolonised education that may include a renewed and even restructured higher education system that is reflective of African thought and heritage (Ajani 2019).

Legal education is distinct from other disciplines and is largely dependent on and determined by the legal framework prevalent in the country at the time. It can be argued that the law has shifted radically with the advent of the South African Constitution in 1996. Included therein are norms and values that permeate all laws (new and old), and the recognition of the need to develop a living customary law in South Africa. Part of this process includes, as highlighted in my argument, various legislative interventions in the legal framework of the country, that together with the Constitution, have allowed the courts to develop customary and common law in line with the principles on the Constitution. The Constitution, which is supposedly located in a western legal paradigm could, however, result in a further erosion of African values, traditions and approaches, but the effect thereof is partially mitigated by the infusion of African values within the Constitutional text. In addition, these natural progressive and piecemeal approaches are slow in changing the legal framework, with the 2015-2016 \#FeesMustFall movement highlighting that western traditions and approaches are still prevalent in higher education. If the natural progressive and piecemeal approaches do not yield results in the timeframes required by society, then perhaps it is necessary to turn to a more radical approach to transform the legal framework that would consequently bring changes to institutional legal education for the decolonisation of legal education. In these circumstances, it is then perhaps worth opening the debate on the viability of codifying the South African legal framework. In doing so, a more unified and consolidated legal system could be created that is not only loyal to its history, but drives the change in thinking and approaches that are relevant and necessary to address contemporary South African issues. 


\section{About the Author}

Michele van Eck | Department of Private Law, University of Johannesburg, South Africa|mmvaneck@uj.ac.za

Michele van Eck is a Senior Lecturer in the Department of Private Law at the Law Faculty of the University of Johannesburg. She is also an admitted attorney of the High Court of South Africa.

\section{Citation}

van Eck, M. (2019). Decolonising legal education in South Africa: Is it time to press the reset button? Journal of Decolonising Disciplines, 1(2): . DOI 10.35293/2664$3405 / 2019 / v 1 n 2 a$ 


\section{References}

Ajani, O.A. (2019). Decolonisation of education in African contexts. African Renaissance, 16(2): 101-120.

Alexkor Ltd and Another v Richtersveld Community and Others 2003 (12) Butterworths Constitutional Law Report 1301 (CC) (accessed via LexisLibrary, LexisNexis 2020).

Allott, N. (1984). What is to be done with African customary law? The experience of problems and reforms in Anglophone Africa from 1950. Journal of African Law, 28(1/2): 56-71.

Archer, P. (1987). Codification of the Law: Ghana's experience. Commonwealth Law Bulletin, 13(3): 1044-1050.

Bekker, J.C. (1989). Seymour's customary law in Southern Africa. 5th edition. Cape Town: Juta.

Bekker, J.C., Rautenbach, C. \& Goolam, N.M.I. (2006). Introduction to legal pluralism in South Africa. 2nd edition. Durban: LexisNexis.

Berat, L. (1991). Customary law in a new South Africa: Proposal. Fordham International Law Journal, 15(1): 92-128.

Berman, J.B. (1977). The origins of western legal tradition. Harvard Law Review, 90(5): 894-943.

Bennett, T.W. \& Vermeulen, T. (1980). Codification of customary law. Journal of African Law, 24(2): 206-219.

Bhe and Others $v$ Magistrate, Khayelitsha and Others; Shibi $v$ Sithole and Others; SA Human Rights Commission and Another v President of the RSA and Another 2005 (1) Butterworths Constitutional Law Report 1 (CC) (accessed via Lexis Library, LexisNexis 2020).

Chaka, C., Lephalala, M. \& Ngesi, N. (2017). English studies: Decolonisation, deparochialising knowledge and the null curriculum. Perspectives in Education, 35(2): 208-229. DOI 10.18820/2519593X/pie.v35i2.16.

Cloete, N. (1991). Codification and stare decisis in a new South African legal order. Tydskrif vir Regswetenskap, 16(1): 58-69.

Cotran, E. (1983). The development and reform of the law in Kenya. Journal of African Law, 27(1): 42-61.

Criminal Code Act 29 of 1960 (as accessed from https://www.wipo.int/edocs/ lexdocs/laws/en/gh/gh010en.pdf on 05.07.2020). 
Criminal Procedure Code Act 30 of 1960 (as accessed from https://www.wipo.int/ edocs/lexdocs/laws/en/gh/gh011en.pdf on 05.07.2020).

Danner, R.A. \& Bernal, M.H. (eds) (1994). Introduction to foreign legal systems. New York: Oceana.

Dlamini, C.R.M. (1992). Towards a new legal order for a new South Africa. Legal Studies Forum, 16(2): 131-144.

Essien, V. (1994). Sources of law in Ghana. Journal of Black Studies (Special Issue: Social, Economic, Political, and Cultural Dimensions of Life in Ghana), 24(3): 246262.

Everfresh Market Virginia (Pty) Ltd v Shoprite Checkers (Pty) Ltd 2012 (3) Butterworths Constitutional Law Report 219 (CC) (accessed via Lexis Library, LexisNexis 2020).

Farnsworth, A. (1964). Law reform in a developing country: A new code of obligations for Senegal. Journal of African Law, 8(1): 6-19.

French Civil Code of 1804 (as accessed from https://www.trans-lex.org/601101/_/ french-civil-code-2016/\#toc_0 on 05.07.2020).

French Civil Code (2016), the Law of Obligations, the General Regime for Obligations, and Proof of Obligations, Ordinance 2016-131, 10 Feb. 2016 (translated by Cartwright, J. and accessed from https://www.trans-lex.org/601101/_/frenchcivil-code-2016/\#toc_0 on 05.07.2020).

Gahan, F. (1922). The codification of law. Problems of peace and war, Papers read before the society. Cambridge University Press on behalf of the British Institute of International and Comparative Law, 8: 107-116.

German Bürgerliches Gesetzbuch of 1900 (as accessed from https://www.gesetze-iminternet.de/englisch_bgb/ on 05.07.2020).

Gower, L.C.B. (1967). Independent Africa: The challenge to the legal profession. Cambridge, MA: Harvard University Press.

Graber, M.A., Levinson, S. \& Tushnet, M. (2018). Constitutional democracy in crisis?. New York: Oxford University Press.

Hahlo, H.R. \& Kahn, E. (1968). The South African legal system and its background. Cape Town: The Rustica Press.

Hammond-Tooke, D. (1964). Chieftainship in Transkeian political development. The Journal of Modern African Studies, 2(4): 513-529.

Himonga, C. \& Nhlapo, T. (eds.) (2014). African Customary Law in South Africa: 
Post-apartheid and living law perspectives. Cape Town and Johannesburg: Oxford University Press.

Himonga, C. \& Diallo, F. (2017). Decolonisation and teaching law in Africa with special reference to living customary law. Potchefstroom Electronic Journal, 20(1): $1-19$.

Hutchison, A. \& Sibanda, N. (2017). A living customary law of commercial contracting in South Africa: Some law-related hypotheses. South African Journal on Human Rights, 33(3): 380-405.

Iya, P. F. (2001). The legal system and legal education in Southern Africa: Past influences and current challenges. Journal of Legal Education, 51(3):355-362.

Kader, A. \& Wilmot, J. (2001). Education and democracy in South Africa today. Daedalus, 130(1): 185-204.

Koma, S.B. (2018). The African renaissance and the impetus for transforming higher education. African Journal of Public Affairs, 10(2): 97-108.

Krzeczunowicz, G. (1963). The Ethiopian Civil Code: Its usefulness, relation to custom and applicability. Journal of African Law, 7(3): 172-177.

Le Roux, M. \& Davis, D. (2019). Lawfare: Judging Politics in South Africa. Johannesburg: Jonathan Ball.

Lemmer, E. \& Olivier, M. (2000). The South African Constitution as post-colonial document: Long walk to freedom. De Jure, 33(1): 138-145.

Levasseur, A.A. (1976). The civil code of the Ivory Coast. Virginia: The Michie Company.

Lokin, J.H.A. (2008). Harmonisation in Roman, Roman-Dutch and South African. Fundamina: A Journal of Legal History, 14(2): 24-36.

Mamdani, M. (2001). Beyond settler and native as political identities: Overcoming the political legacy of colonialism. Comparative Studies in Society and History, 43(4): 651-664.

Modiri, J.M. (2019). Race, history, irresolution: Reflections on city of Tshwane Metropolitan Municipality v Afriforum and the limits of "post"-apartheid constitutionalism. De Jure, 52(1): 27-46.

Molope, M. \& Mekoa, I. (2018). Decolonising the curriculum: The case of development studies. Journal of Gender, Information and Development in Africa, 7(1): 139-159.

Myburgh, A.C. (1985). Papers on indigenous law in Southern Africa. Pretoria: Van Schaik. 
Ndima, D.D. (2003). The African law of the 21st century in South Africa. The Comparative and International Law Journal of Southern Africa, 36(3): 325-345.

Olivier, N.J.J., Bekker, J.C., Olivier N.J.J. (Jnr) \& Olivier, W.H. (1995). Indigenous law. South Africa: Butterworth.

Port Elizabeth Municipality v Various Occupiers 2004 (12) Butterworths Constitutional Law Reports 1268 (CC) (accessed via Lexis Library, LexisNexis 2020).

Rautenbach, C. \& Bekker, J.C. (2014). Introduction to legal pluralism. Pietermaritzburg: LexisNexis.

Rosenfeld, M. \& Sajó, A. (eds) (2013). The Oxford handbook of comparative constitutional law. New York: Oxford University Press.

RSA (Republic of South Africa). 1927. Black Administration Act 38 of 1927. Pretoria: Government Printing Works.

RSA (Republic of South Africa). 1953. Bantu Education Act 47 of 1953. Pretoria: Government Printing Works.

RSA (Republic of South Africa). 1996. Constitution of the Republic of South Africa Act 108 of 1996. Pretoria: Government Printing Works.

RSA (Republic of South Africa). 1993. Constitution of the Republic of South Africa Act 200 of 1993. Pretoria: Government Printing Works.

RSA (Republic of South Africa). 2008. Consumer Protection Act 68 of 2008. Pretoria: Government Printing Works.

RSA (Republic of South Africa). 1959. Extension of University Education Act 45 of 1959. Pretoria: Government Printing Works.

RSA (Republic of South Africa). 1996. Land Reform (Labour Tenants) Act 3 of 1996.

Pretoria: Government Printing Works.

RSA (Republic of South Africa). 1998. Law of Evidence Amendment Act 45 of 1988.

Pretoria: Government Printing Works.

RSA (Republic of South Africa). 2014. Legal Practice Act 28 of 2014. Pretoria: Government Printing Works.

RSA (Republic of South Africa). 2005. National Credit Act 34 of 2005. Pretoria: Government Printing Works.

RSA (Republic of South Africa). 1997. Qualifications of Legal Practitioners Amendment Act 78 of 1997. Pretoria: Government Printing Works. 
RSA (Republic of South Africa). 2009. Reform of the Customary Law of Succession and Regulation of Related Matters Act 11 of 2009. Pretoria: Government Printing Works.

RSA (Republic of South Africa). 1998. Recognition of Customary Marriages Act 120 of 1998. Pretoria: Government Printing Works.

RSA (Republic of South Africa). 2005. Restitution of Land Rights Act 22 of 1994. Pretoria: Government Printing Works.

RSA (Republic of South Africa). 2003. Traditional Leadership and Governance Framework Act 41 of 2003. Pretoria: Government Printing Works.

Sanders, A.J.G.M. (1981). The characteristic features of southern African law. The Comparative and International Law Journal of Southern Africa, 14(3): 328-335.

Sanders, A.J.G.M. (1987). How customary is African customary law? The Comparative and International Law Journal of South Africa, 20(3): 405-410.

S v Makwanyane and Another 1995 (6) Butterworths Constitutional Law Report 665 (CC) (accessed via Lexis Library, LexisNexis 2020).

Thomas, P.H.J. (2008). Harmonising the law in a multilingual environment with different Legal systems: Lessons to be drawn from the legal history of South Africa. Fundamina: A Journal of Legal History, 14(2): 133-154.

Van der Walt, A.J. (2006). Legal history, legal culture and transformation in a constitutional democracy. Fundamina: A Journal of Legal History, 12(1): 1-47.

Van Niekerk, G.J. (2011). Orality in African customary and Roman law of contract: A comparative perspective. De Jure, 44(2): 364-380. 
